\title{
HTR Centennial Celebration: Words of Welcome
}

\section{Citation}

Graham, William A. 2008. HTR Centennial Celebration: Words of Welcome. Harvard Theological Review 101, no. 3/4: 291-294.

\section{Published Version}

10.1017/S001781600800182X

\section{Permanent link}

http://nrs.harvard.edu/urn-3:HUL.InstRepos:12215653

\section{Terms of Use}

This article was downloaded from Harvard University's DASH repository, and is made available under the terms and conditions applicable to Other Posted Material, as set forth at http:// nrs.harvard.edu/urn-3:HUL.InstRepos:dash.current.terms-of-use\#LAA

\section{Share Your Story}

The Harvard community has made this article openly available.

Please share how this access benefits you. Submit a story.

\section{Accessibility}




\title{
HTR Centennial Celebration: Words of Welcome
}

\author{
William A. Graham, Dean \\ Harvard Divinity School
}

Good morning and welcome to all of you who have gathered on this extremely proud day for Harvard Divinity School to mark the centennial celebration of the $H T R$, the Harvard Theological Review.

I am honored to have been asked by our Editor, François Bovon, to begin the day by paying brief tribute to this trail-blazing publication in theological and religious studies, and especially in American theological and religious studies. Since its first print run in 1908, the Review has had a significant role in defining the ways in which essential religious questions are posed, analyzed, and taken in new and compelling directions in scholarship, both in this country and abroad.

However, we should not think today that this was, even in the beginning, a hundred years ago, an undertaking that had smooth sailing. One can glean something of that, I think, from the very first article in the inaugural HTR issue, 1:1, of January 1, 1908, which was written by Francis Peabody and entitled "The Call to Theology." In his very first paragraph, Peabody remarks that theology was not uncontested in society at large, however positively it might have been treated in the academy at the time:

The time may appear to many persons inopportune for the launching of a Journal of Theology. The tide of theological interest may seem to have ebbed so low as to leave no channel for such a venture; the profession of the ministry fails to win recruits; the queen of the sciences is deposed from her throne; critics are announcing the rout of the theological schools. The machinery of the churches, it is true, revolves with energy, but it does not seem to be geared into the wheels of the working world; and the deliberations of the theologians are frankly regarded by great numbers of people with indifference, if not with contempt. A distinguished railway president, on being informed that a promis-

HTR 101:3-4 (2008) 291-94 
ing youth had undertaken the study of theology, remarked, "Why does not so gifted a man devote himself to something that is real?"

These very first words of the first article of the new HTR indicate pretty clearly that there were obstacles, or perhaps challenges, that scholars could see in front of them as the HTR was founded (and to which Peabody and his colleagues evidently felt the new journal could respond). Of course, we know today that despite such social counter-currents, the Review and the field of theology did not after all wither away. The HTR set out to broaden, and indeed did broaden, the very definition of theological studies in the course of the past century. It did so in such a way as to help this field encompass critical aspects not only of normative theological thinking, but also, and indeed prominently so, of history, philosophy, ethics, sociology, economics, and education as they pertain to religion, and as they affect people of all faiths, around the world. The mission statement that appeared with that first issue of the Review signaled this ambitious reach, noting that the journal "... will endeavor to maintain a spirit at once catholic and scientific, in sympathy with the aims and activities of the Church, as well as with scholarly investigation."

Over the past 100 years, the HTR has certainly met these goals; and I think you would all agree that it has, in fact, far exceeded them. The publication's scholarly yet accessible articles have challenged students of theology and religion around the globe to change and deepen their understanding of many topics, from Hebrew Bible and New Testament and early archaeological findings to ethics, women's studies, and comparative religion.

It may be especially relevant for me as the current dean of the Divinity School, given the leading role that HDS has taken, for example, in Women's Studies in the past thirty-five years, to note that the HTR published articles by female scholars almost from the beginning. One could point especially to the article from HTR 4:4, in 1911, by Mary Whiton Calkins of Wellesley College, entitled "The Nature of Prayer." This paper had been given as a lecture at the Harvard Summer School of Theology in 1910. Calkins was Professor of Greek and a noted psychologist. She had studied and completed virtually perfect doctoral examinations at Harvard under William James and Hugo Munsterberg, but despite support from James and also Josiah Royce, two of the University's most distinguished scholars, Harvard had refused to grant her the doctorate. When offered instead a Ph.D. from Radcliffe, Calkins had turned it down. She went on, however, without a formal Harvard Ph.D. to become President of both the American Psychological Association (1905) and the American Philosophical Association in 1918. So the $H T R$ was already out in front of its own institution in its early days!

I might also mention the readiness of the early $H T R$ editors to reach beyond the confines of the western academy for authors: witness the early contribution, "Emerson from an Indian Point of View," by Herambachandra Maitra, Calcutta, India, in which the author comments as follows on an earlier Harvard Divinity School graduate of some renown: 
Emerson appeals to the Oriental mind. He translates into the language of modern culture what was uttered by the sages of ancient India in the loftiest strains. He breathes a new life into our old faith, and he assures its stability and progress by incorporating with it [other] truths revealed or brought into prominence by the wider intellectual and ethical outlook of the modern spirit.

Over the years, the $H T R$ has attracted contributions from a wide variety of prominent scholars from this continent and abroad: Karl Bornhausen (Marburg, 1914), Ernst von Dobschütz (Halle, 1913), and Ernst Troeltsch (Heidelberg, 1912 - an article in memory of William James) are three early contributors of international fame. Later authors from various fields and disciplines include scholars such as W. D. Davies, H. A. R. Gibb, Bruce Metzger, George Lindbeck, Jürgen Moltmann, David Noel Friedman, E. P. Sanders, Paul Ricœur, Paul Tillich, Victor Turner, Jonathan Z. Smith, and Martin Marty, not to mention the many Harvard scholars from FAS and HDS who have written over the decades, or still do write today, for the HTR.

François Bovon, our current editor and a frequent contributor himself to the HTR, has carried forward in exemplary fashion the long tradition of general scholarly excellence as well as the particularly prominent and excellent tradition of New Testament scholarly contributions to the Review in the past half-century. Like his predecessors, such as our distinguished emeritus colleague, Helmut Koester, who will be presenting a paper this morning, François has managed to continue and to improve a venerable publication on a limited budget and with remarkable resourcefulness for the last number of years. This has of course been possible to no small extent because of the remarkable editorial work of the indefatigable Margaret Studier and many of our own doctoral students, who continue to make this publication all that it is. I particularly congratulate François this morning, and I thank Margaret and her editors, as well Helmut and the many HDS faculty who have served on the editorial board and/or vetted article submissions for publication repeatedly and conscientiously.

I know that we shall all now enjoy the presentations and discussions to follow today; I hope also that everyone here will read through the special 100th anniversary double issue of the Harvard Theological Review - a wonderful publication scheduled to appear this coming fall and winter, and which will include today's papers. In addition, I encourage you to visit the online index on the Harvard Theological Review website when it goes "live." It will be a fantastic resource that lists every article published in the Review on a particular topic. It should be clear that we have much to look forward to from the $H T R$, as we help it enter its second century; we celebrate today not its conclusion, but rather only a notable milestone on what we hope and trust will be a much longer path to an even more distinguished future. 
It is now my pleasure to introduce François Bovon, the Frothingham Professor of the History of Religion and my esteemed colleague - whom I admire greatly as a scholar and on whom I have constantly relied in many ways as a colleague since becoming dean (and he has never let me or his faculty colleagues down). It is a privilege to call him a friend and colleague and to be able to introduce him today. 